\title{
Children with Disabilities: an Analysis of a Learning Process in the Early Years' Classroom Toward Inclusive Practice
}

\author{
Diana Diana \\ Early Childhood Teacher Education Departement, \\ Semarang State University \\ Central Java- Indonesia \\ diana@mail.unnes.ac.id
}

\author{
Edi Waluyo \\ Early Childhood Teacher Education Departement, \\ Semarang State University \\ Central Java- Indonesia \\ waluyowulan@gmail.com
}

\author{
Amirul Mukminin \\ Early Childhood Teacher Education Departement, Semarang State University \\ Central Java- Indonesia \\ mirpoerjo@yahoo.co.id
}

\begin{abstract}
Inclusive education services for early childhood are expected to provide opportunities for all children regardless of their conditions to be able to obtain equal rights in education and learning process. The number of early childhood students with special needs increases each year, but the education services that can be provided by early childhood institutions are still very minimal.Inclusion involves creating situations in the setting that support the needs of the student; mainstreaming children, on the other hand, involves having students with disabilities learning to be in a general education setting [1].Teachers' knowledge of the condition and diversity of children with disabilities is still said to be lacking as well. Similarly, the implementation process of learning for children with special needs has not been well enough. This study aims to analyze the needs of early childhood learning in schools for children with special needs, so that later the school can design and provide the appropriate learning experience in inclusive early childhood education Introduction The result of data analysis shows that there is no clear reference related to the curriculum, planning and learning assessment standard for early childhood students with disabilities. In addition, the means associated with the mobility of children in learning activities is still very minimal. It can be concluded that inclusive early childhood education needs to have individual education program and supporting infrastructure in learning activity.
\end{abstract}

Keywords-- an analysis of learning; children with disabilities; inclusive practice.

\section{INTRODUCTION}

\section{A. Background}

Nowadays, human beings are viewed as the being of Bhinneka (individual differences). Disability or superiority is a form of human diversity [2]. With such a view, the segregation of children into normal and special need groups becomes irrelevant. Children with special needs do not have to be in secluded schools, but also included in public institutions.
Although since August 11 2004, through a declaration in Bandung, Indonesia has committed Towards Inclusive Education, where the statement is providing an education for all by giving opportunity to all children without exception to get the same education. However, there has not been any significant practical implementation [3].

The increasing number of children with special needs each year provides the chance for Early Childhood Education (ECE) institutions to assist in education for special needs with limited number of services to children with special needs. It is hoped that if there is a standardized curriculum for early childhood with special needs, the inclusive education program proclaimed by the government can assist in teachers in preparing programs for children with special needs in inclusive classes. Many professionals agree that an important dimension of inclusion is that children with disabilities attend the same class as typically developing children (i.e., attending the same hours in the same classroom) rather than being in different classes and just sharing joint activities for aportion of the day [4].

Some institutions that have implemented this program also apparently cannot provide maximum services for children with special needs. Most of these institutions only use inclusive education as branding strategy. But in reality this institution has not been able to maximally meet the needs of children with special needs. This type of ECE institutions usually only go as far as admitting children with special needs as their students, but even then, the children with special needs are usually still in a "light" category, while those who really belong to the children with special needs group cannot be accepted by the institutions. If it is also noticed that the children are considered to have medium and heavy needs, they are not included in the special needs institutions that have limited space and facilities, so they cannot be accommodated nearly anywhere. 
Inclusive ECE becomes one of the place for children with the need to obtain educational services equivalent to those without special needs. Learning activities are tailored to the specific needs of the child, so they get the same service. One of the challenges faced by education systems in around the world is inclusion. It is not simply about placing pupils with SEN (Special Education Needs) in mainstream classrooms, but also examines about the quality of education received by all groups of learners and includes student's presence, participation, acceptance, and achievement [5]. To meet the needs of children with special needs requires a needs analysis, so that later, the learning process will be in accordance with the expected goals. Needs analysis becomes an important part for an educator to know what the child needs in the learning process. The purpose of this study is to analyze the needs of children who have special needs, which can be used by educators as a basis in making learning plans in inclusive early childhood institutions.

\section{LITERATURE RIVIEW}

\section{A. Needs Analysis}

Need Assessment (a needs analysis) is a method to find out the difference between the desired or expected condition (should be / ought to be) with the existing condition (what is). The Needs Analysis Method is designed to measure the gaps that occur in student learning from what is expected and what has been obtained.

The needs analysis steps are described by Glasgow in the form of activities starting from the stage of gathering information to formulating the problem. While Morrison describes needs analysis in the form of activities starting from planning to making the final report.

\section{B. Children with Special Needs}

Children with special needs are children who have abnormalities/ deviations from the average condition of normal children generally in terms of physical, mental and social behavior characteristics. Children with special needs will certainly face various problems related to the specific needs. All these problems need to be resolved by providing educational services, guidance and training so that all the problems that arise can be solved well. For that, teachers or parents need to understand the needs and potential of children in order to develop maximally according to their special needs [6].Children with special needs are defined as individuals who have different characteristics from other individuals that are considered normal by society in general. More specifically, special needs children exhibit lower or higher physical, intellectual, and emotional characteristics of normal children or beyond the normal standards of society. So these type of children have difficulties in achieving success in terms of social, personal, and educational activities [7].

Children with disabilities has a broader meaning when compared with the meaning of extraordinary children. Children with special needs are children whose education requires specific and different services with children in general. Children with special needs are experiencing barriers in learning and development, either due to lack or excessive potentials possessed by the child. Therefore they need an education service that suits their individual learning needs [8].

Full inclusive education program from Kauffman \& Hallahan[9] means: (1) all children with special needs, regardless of the type or severity of the disorder will attend regular classes. Thus, there are no separate classes of special education; (2) all children with special needs attend school in close proximity to their residence, or school that they will attend if they do not have special needs; (3) general or regular education is the institution that has primary responsibility for children with special needs.

The implementation of inclusive education in Indonesia is actually guaranteed through the Indonesian minister of education and culture regulation no. 70 year 2009 Article 1 which states that Inclusive education is defined as an education delivery system that provides opportunities for all learners who have special needs and have the potential of intelligence and/ or special talents to follow education or learning in an educational environment together with learners in general. The constitutional provision assures that there is no distinction in terms of treatment and opportunity to obtain education for all learners, who have special needs and special talents to attend education together with other typical learners. Inclusion has evolved to mean that children with disabilities not only attend the same programs/spaces as children without disabilities, but that they participate fully in the program through accommodations and modifications [10].

\section{RESEARCH METHOD}

This research used quantitative approach to process the data obtained from the location of research, where the quantitative data according to Sugiyono [11] is the data in the form of numbers or qualitative data that is converted into numbers. The basis of this study is survey research, which is to divide the questionnaire to the respondent which contains questions on matters relating to child needs analysis of disability.

The population in this study is all educators who teach children with special needs of preschool age in special needs institutions in Semarang City. The samples in this study are 18 teachers who teach for the early age group.

\section{RESULT AND DISCUSION}

Special needs education is a place of formal education for children with disabilities/ special needs. They are; children with visual impairment, hearing impairment, physical disabilities, mental disabilities, and emotional disabilities. Mangunsong [12] categorizes the program of learning activities at special needs institutions as follows: (1) Common programs in the form of: behaviors through habituation embodied in daily activities, including civics, religion, discipline, feelings/ emotions, and social skills; as well as the 
development of basic capabilities including language, cognitive capacity, creativity, skills and physical education. (2) The special programs in a form of orientation and mobility for visually-impaired students, sound perception and rhythm development for hearing-impaired students, the ability to care for children with light to medium mental disability, selfbuilding and movement for phisically-impaired students. Children need adults to help assess the limits of shame and doubt so that they become independent. Foster self- reliance is the responsibility of parents/families, teachers/school, and community [13]

Based on the results of needs analysis on the learning program for children with special needs in educational institutions that specifically handle the children, it was found that in the learning process $78 \%$ of teachers have met the supporting aspects of learning in accordance with the needs of the students, the remaining $22 \%$ is knowledge related teachers with the curriculum renewal and appropriate infrastructure. It is recommended to promote any activities on in-creasing social awareness on disability and the social status of children with dissabilities. In which children with dissabilities are able to attend, to make their voice and to contribute to. School setting is the most significant one for children with dissabilities to make any changes on their social awareness and on accessing the sustain- able inclusion process [14].

Referring to the results of the above data, it can be described that the analysis of learning needs in early childhood start on the most fundamental aspect which is related to the curriculum. The education curriculum for children with dissabilities needs is structured to realize the national objectives, taking into account the developmental stages of learners who bear physical and / or mental and / or behavioral disabilities, and their compatibility with the environment, national development needs, the development of science and technology as well as arts, and the level of disabilities as well as levels of each unit of education [12]. In addition, infrastructure facilities become an important part in implementing curriculum in a process of learning activities. If we take a look at the survey results that have been done, it is the complete opposite of the reality in the field. The infrastructure facilities in special needs institutions that handle early childhood students provide very minimal services. Playing as the basic needs of early childhood becomes an important part for teachers in making learning plans and designing playing activities in early childhood. Whatever constraints/ disabilities that the children have, they need activities that can channel their natural needs in order to optimize their growth and development. Learning models and environmental settings also provide an important role for teachers in planning activities for children. It is important to understand that special needs education is not a comprehensive education; it is different from education for children in general [15]. Teachers should also be able to design a learning activity program containing a holistic and integrative element. Holistic here means learning activities are expected to be comprehensive in every aspect of development that are related to each other. Therefore, it is beneficial in optimizing the growth and development not only on one or two aspects of development, but the entire aspect of development.

Learning is the change of behavior acquired by individual experiences. Joyful student-centered learning experiences positively influence a child's interest creativity, initiative and confidence, which are critical skills for a successful life [16].

Integrative here can be interpreted that learning activities in early childhood students who have special needs must be integrated with various services, such as health and nutrition, parenting and protection for the children. In this case, the special needs institutions that handle early childhood have not touched this aspect. Every child is a whole being, that is why holistic and integrative education is needed in order to fulfill the children's right. Early childhood inclusion is a primary placement for special education services for a substantial number of children with disabilities. The research and professional literature since the passage of the Handicapepped Act (PL 99-457) has provided important findings related to outcome and benefits for children, specialized instruction, collaboration among adults, and necessary supports [17].

\section{CONCLUSION}

Based on the results and discussion above, it can be concluded that the analysis of learning needs for early childhood with special needs is started from the standard curriculum that will be described in the learning program. Teachers also need to understand about learning theories for children, the stage of playing and always stay updated with the curriculum and that will help them in designing learning for early childhood. In addition, facilities that support the learning process become an important part, as well as the provision of instructional media, educational tools both indoor and outdoor.

\section{RECOMMENDATION}

This research is expected to provide readiness of teachers in Inclusive Early Childhood Institutions to be ready to accept students with various limitations, and prepare programs/ learning activities in various ways according to the needs and characteristics of the children.

\section{References}

[1] Onaga, E. E., \& Martoccio, T. L. (2008). Dynamic and Uncertain Pathways between Early Childhood Inclusion Policy and Practice, 2(1), $67-75$.

[2] Marthan, LK. (2007). Manajemen Pendidikan Inklusif. Jakarta: Departemen Pendidikan Nasional.

[3] Lokakarya Nasional : Towards Inklucion : Menuju Inklusi. (online). http://www.idp- europe.org/docs/Bandung_Declaration.pdf. (Diunduh 5 Januari 2017).

[4] Odom, S. L. (2000). Preschool Inclusion: What We Know and Where We Go From Here. TECSE 20:1, 20-27. 
[5] Windiarti, R. (2015). Indonesian Journal of Early Childhood INCLUSIVE CLASSROOM: SOME LESSONS FROM THE UK inclusion. It is not simply about placing pupils with SEN in mainstream, 4(2), $1-16$.

[6] Abdulah. (2013). Mengenal Anak Berkebutuhan Khusus. Jurnal Fakultas Ilmu Pendidikan Universitas Sumatra Utara.

[7] Tentama. (2010). Berpikir Positif dan Penerimaan Diri pada Remaja Penyandang Cacat Tubuh Akibat Kecelakaan. Humanitas, Vol. VII. No. 1, Januari.

[8] Nur'aeni. (1997). Intervensi Dini bagi Anak Bermasalah. Jakarta: PT Rineke Cipta.

[9] Hallahn, D.P. \& Kaufman, J.M. (2006). Exceptional learners: An Introduction to Special Education. $10^{\text {th }}$ Ed. USA: Pearson Education, Inc.

[10] Halfon, S. (2013). Inclusion of young children with disabilities in regulated child care in Canada A snapshot: Research, policy and practice Occasional Paper No . 27.

[11] Sugiyono. (2009). Metode Penelitian Pendidikan. Bandung: Alfabeta.

[12] Wantoro, D., Kurniawati, Y., \& Pranoto, S. (2014). Indonesian Journal of Early Childhood The Application Language Ability Development on 3-5 Year Children with Hearing Dissability, 3(2), 134-138. http://doi.org/10.15294/ijeces.v3i2.9487

[13] Mangunsong, Frieda. (2011).Psikologi dan Pendidikan Anak Berkebutuhan Khusus; Jilid 2. Depok: LPSP3 Kampus Baru UI.

[14] Tran, K. V. (2014). Exploring the experience of children with disabilities at school settings in Vietnam context. Springer Journal Open Acces, Vol.3(103), 1-11.

[15] Kirk, S.A, \& Gallagher, J.J. (1986). Educating Exceptional Children. $3^{\text {rd }}$ Edition. USA: Houghton Mifflin Co.

[16] Raman, V. S., \& Joshi, I. (2011). Building Communities for Change : An Experience in Mumbai. International Journal of Child Care and Education Policy, 5(2), 57-65.

[17] Odom, S. L. (2011). Inclusion for Young Children With Disabilities : A Quarter Century of Research Perspectives. Journal of Early Intervention, Volime 33(Number 4), 344-356. 